\title{
Lessons on broodstock maintenance, spawning, larval rearing and juvenile production of marine gastropods of ornamental value
}

\author{
Iyadurai Jagadis $^{1}$, Mookaiah Kavitha ${ }^{1}$, Jaganathan Padmanathan ${ }^{1}$, Ashok Maharshi ${ }^{2}$ \& \\ Arumugam Varadarajakumar ${ }^{1}$ \\ ${ }^{1}$ Tuticorin Research Centre, Central Marine Fisheries Research Institute (CMFRI), Tuticorin, Tamil Nadu, India \\ ${ }^{2}$ Mandapam Regional Centre, Central Marine Fisheries Research Institute (CMFRI), Ramanathapuram, Tamil Nadu, India
}

Correspondence: Dr. I Jagadis, Principal Scientist, Tuticorin Research Centre of CMFRI, South Beach Road (Near Rochi Park), Tuticorin 628 001, Tamil Nadu, India. E-mail: iyaduraijagadis@gmail.com

\begin{abstract}
Research on marine gastropod breeding in India is in its infancy and scanty literature is only available. To fill the lacunae, marine gastropods of three ornamentally valued and conservation important groups such as Cyprids, Strombids and Muricids were held under captivity and studied for their broodstock maintenance, spawning behaviour, larval rearing and metamorphosis into juveniles at the Shellfish Hatchery of Central Marine Fisheries Research Institute, Tuticorin. Valuable information on the focal themes of the article was obtained for Strombids and Muricids leading to the successful life cycle closing for Lambis lambis and Chicoreus virgineus are reported earlier. In the present study, experiments were conducted on aspects such as post-metamorphosed juvenile rearing up to 76 days post hatch for L. lambis, spawning, larval development and life cycle closing and reasonable level of juvenile production $(8.8 \%)$ for Chicoreus ramosus. In addition, the primary observations on the captive breeding of Cypraea tigris with reference to its egg mass, brooding habit and early development is reported. However, while studying these groups few unanswered questions and bottle necks in their breeding nature, larval rearing and metamorphosis arose. The following account details the experiments conducted and results obtained in each of the focal themes of the paper and the constraints faced.
\end{abstract}

Keywords: controlled breeding, larval rearing, ornamental gastropods, Cyprids, Strombids, Muricids

\section{Introduction}

Studies on the captive breeding of tropical and temperate marine gastropods has drawn only little attention of the researchers. This probably due to its complexity in the larval maintenance and identification of appropriate feed for the different stages of the larvae, determination of ambience, infections during the larval rearing course and as well rearing to its 'competency level' and identification of proper 'cue' to settle the competent larvae as juveniles. Literature survey reveals a worldwide attention on breeding of marine gastropods and only limited success reported in India or elsewhere. To mention few, the success achieved in Strombus gigas (Brownell 1977; Davis 2000; Manzano \& Aranda 2004; Shawl \& Davis 2004), in Trochus sp. (Heslinga \& Hillmann 1981) and in Muricids (Middelfart 1992; Nugranad 1992; Mahmoud, Mohammed \& Yassien 2013). In India, systematic studies on captive breeding and life cycle closings have been successfully made on few marine gastropods especially on Abalone Haliotes varia (Najmudeen \& Victor 2004), Babylonia spirata (Shanmugaraj, Murugan \& Ayyakkannu 1994; Sreejaya, Mohan, Laxmilatha \& Appukuttan 2004), Lambis lambis (Jagadis, Shanmugasundaram \& Padmanathan 2012), Chicoreus virgineus (Jagadis, Shunmugasundaram, Sathakkathulla \& Mohanraj 2013) and Hemifusus pugilinus (CMFRICadalmin 2012).

Wild collected broodstocks of three groups of commercially important gastropods were held under captive condition during 2012-2015 and 
studied for their brood maintenance requirements such as environmental ambience, specific feed protocols both for brooders and larvae and larviculture till juvenile stage.

In the present paper, (1) the post-metamorphic developments in L. lambis; (2) detailed and complete larval development sequence and juvenile production in Chicoreus ramosus and (3) the preliminary observations made on captive maintenance and breeding of Cypraea tigris are detailed.

\section{Materials and methods}

Broodstock maintenance of L. lambis, C. ramosus and $C$. tigris

Broodstocks of all the three species i.e., L. lambis, C. ramosus and $C$. tigris belonging to the families Strombidae, Muricidae and Cypraeidae, respectively, were collected fresh from the landing centre and transported to the Shellfish hatchery in an aerated seawater container. The collected brooders were sexed wherever possible and maintained at the rate of 10 brooders for the former two groups and six numbers for the later in each one tonne FRP tanks. A standard volume of $750 \mathrm{~L}$ of filtered seawater was maintained throughout the rearing. The tanks were fitted with an airlift system made of PVC pipes and connected to air blowers for continuous re-circulation of seawater. The overturn of the seawater was so adjusted to have 300\% exchange is effected in $24 \mathrm{~h}$. The bottom of the brood maintenance tanks was filled with sand to a height of $10 \mathrm{~cm}$.

\section{Spawning and larval development of $C$. ramosus and $C$. tigris}

Survival of the brooders of Strombids, Muricids and Cyprids were observed year round by maintaining the brooders and fed with either live macro algae or live clams depending upon the feeding behaviour. The brooders were daily observed for their breeding behaviour, mating and egg laying process. After spawning the egg cases were collected from the brooder tank and counted and kept in separate FRP tank for incubation. The fecundity was estimated by observing the number of eggs in a single egg case and raising to total number of egg cases laid. To study the viable larval production potential of C. ramosus 30 egg cases from three egg clusters were carefully removed after
1 week of spawning and kept it in a $3 \mathrm{~L}$ capacity glass container with mild aeration and were monitored up to hatching. Concurrently details on the morphology of egg cases, number of egg cases laid, hatched, un-hatched and decayed egg cases were also recorded for fecundity estimation. The embryonic and larval developments were observed and photographed using stereozoom microscope at periodical interval.

Since the number of egg cases laid by the Cyprid brooder could not be counted due to its brooding behaviour the egg cases were allowed to hatch. Before hatching an egg case was cut open and the number of eggs within was counted. The total hatched larval number was divided by this number to arrive at the number of egg cases laid.

Day 1 veligers are collected through a fine meshed nylon bolt sieves and stocked in different sized 3, 5, $10 \mathrm{~L}$ glass rearing containers at a stocking density of 100 numbers $\mathrm{L}^{-1}$ of sea water. Appropriate concentrations of Isochrysis galbana were fed to the larvae daily during morning hours. The growth, percentage survival, mortality of stocked larvae were recorded on regular intervals. The larvae reared are allowed to settle naturally in Muricids. The hydrological parameters of water such as temperature, $\mathrm{pH}$, salinity, dissolved oxygen and ammonia were recorded in the larval rearing tank once in a week.

\section{Metamorphosis induction experiments}

Metamorphosis induction of the competent larvae of $L$. lambis i.e., 18 days post hatch were attempted with chemical and natural cues such as $\mathrm{H}_{2} \mathrm{O}_{2}$ at the rate of $10,50,100,500 \& 1000 \mu \mathrm{M}$ concentration (Boettcher, Dyer, Casey \& Targett 1997), $\mathrm{KCl}$ at $15,50 \& 100 \mu \mathrm{M}$ concentration (Cob, Arshad, Ghaffar, Bujang \& Muda 2010) and Sargassum crude extract in the concentration of $100 \mathrm{mg} \mathrm{L}^{-1}$ have been attempted. The experiment was carried out in $500 \mathrm{~mL}$ glass beaker containing $300 \mathrm{~mL}$ fresh seawater. All the treatments were conducted in triplicate and each replicate was given an exposure time of $6,12,24$ and 48 h to determine the metamorphosis potential of each cues.

\section{Disease management}

During the course of the larval rearing of the three groups of gastropods, ciliate infection was the major problem encountered. To protect the larvae 
from ciliate infection, the larvae were first filtered and kept in the sieve itself and dipped for $10 \mathrm{~min}$ in $25 \mathrm{mg} \mathrm{L}^{-1}$ Chloramphenicol (antibiotic for bacterial infections) solution prepared with fresh filtered seawater and later released to the respective culture containers.

\section{Results}

Broodstock maintenance of L. lambis, C. ramosus and C. tigris

Cent per cent survival of brooders of all the three species L. lambis, C. ramosus and C. tigris were observed in the Shellfish hatchery, CMFRI, Tuticorin. (Table 1). Strombids being an herbivore, algal encrusted stones having Ulva sp. was provided at the rate of $600 \mathrm{~g}$ of wet weight for 10 brooders once in 4 days. The feeding rate was found to be sufficient and the brooders were healthy throughout the period of maintenance over years and matured, mated and spawned. The muricid brooders were supplied with live clams as feed at the rate of 20 clams ( $20 \mathrm{~g}$ flesh weight) for 10 brooders once in 2 days which proved to be sufficient during the period of maintenance of more than 2 years (Table 1). In the present experiment the cyprid brooders were fed with macro algal diet of Ulva sp. ad libitum and the brooders were found to rasp the algae and survived over years of maintenance. The environment parameter in the rearing tank fluctuated within ambience (Table 2).

Spawning and larval development

Strombids - L. lambis

Larval production and post-metamorphic development. Brooders of L. lambis with the size/ weight range of $127-177 \mathrm{~mm}$ (average size $149 \mathrm{~mm}$ )/270-370 g (average weight $352 \mathrm{~g}$ ) maintained in the shellfish hatchery spawned during December 12 and the egg strands were collected and reared following the method as described by Jagadis et al. (2012) and the late development stages of metamorphosed juvenile has been successfully studied up to 76 days post hatch (Fig. 1a-d). The metamorphosis of the larvae was observed to be similar till $18 \mathrm{dph}$ as in the earlier observation; however, the size of the pre juvenile was slightly larger. The pre juvenile on $22 \mathrm{dph}$ was $2.2 \mathrm{~mm}$, on $43 \mathrm{dph}$ it was $4.17 \mathrm{~mm}$ and had developed three whorls. Thereafter, the juveniles showed rapid growth rate and reached $7.0 \mathrm{~mm}$ on $55 \mathrm{dph}$ and $11-18 \mathrm{~mm}$ in length and $6.6-9.1 \mathrm{~mm}$ in shell diameter on $76 \mathrm{dph}$ and had developed five whorls. The shell colour was pale brown to brown and had dark brown dots and blotches on the body whorl. The body whorl also had three circumventing rings. The edges of the siphonal canal showed signs for development of spines. The juveniles were fed ad libitum with Ulva sp. which was well-accepted and the juveniles grazed on the macro alga supplied (Table 3).

Muricids - C. ramosus

The size and weight of the brooders of C. ramosus maintained over the years ranged from 194 to $201 \mathrm{~mm}$ (average size $185 \mathrm{~mm}$ ) and 760-1050 g (average weight $896 \mathrm{~g}$ ). The brooders started spawning from January 2015 and continued up to March 2015. Two females spawned successfully. During the spawning C. ramosus laid the egg cases in clusters on the tank walls. The first female laid one egg cluster and the second female laid three egg clusters. A total of 1616 egg cases have been

Table 1 Details of brood stock maintenance and feeding protocol

\begin{tabular}{|c|c|c|c|c|c|c|c|c|}
\hline Species & $\begin{array}{l}\text { Number of } \\
\text { brooders } \\
\text { maintained }\end{array}$ & \multicolumn{2}{|c|}{$\begin{array}{l}\text { Period of } \\
\text { maintenance } \\
\text { (in years) }\end{array}$} & $\begin{array}{l}\text { Stocking } \\
\text { density } \\
\text { (numbers } \\
\text { per ton) }\end{array}$ & Sex ratio & $\begin{array}{l}\text { Size } \\
\text { range }(\mathrm{mm})\end{array}$ & $\begin{array}{l}\text { Weight } \\
\text { range }(g)\end{array}$ & $\begin{array}{l}\text { Survival } \\
\text { rate (\%) }\end{array}$ \\
\hline Lambis Lambis & 40 & $>2$ & & 10 & $1: 1$ & 129-177 (149) & $270-450(352)$ & 100 \\
\hline Chicoreus Ramosus & 20 & $>2$ & & 10 & Unsexed & 94-201 (185) & $760-1050(896)$ & 100 \\
\hline Cypraea tigris & 6 & $>1$ & & 6 & Unsexed & 83-96 (89) & $165-230(197)$ & 100 \\
\hline \multicolumn{2}{|l|}{ Parameter/species } & \multicolumn{3}{|c|}{ Lambis lambis } & \multicolumn{2}{|c|}{ Chicoreus ramosus } & \multicolumn{2}{|c|}{ Cypraea tigris } \\
\hline \multicolumn{2}{|l|}{ Feed } & \multicolumn{3}{|c|}{ Ulva sp. } & \multicolumn{2}{|c|}{ Clam meat } & \multicolumn{2}{|c|}{ Ulva sp. } \\
\hline \multicolumn{2}{|c|}{ Feeding rate $\left(\mathrm{g}\right.$ brooder ${ }^{-1}$ day $^{-1}$ ) } & \multicolumn{3}{|c|}{15} & \multicolumn{2}{|l|}{2} & \multicolumn{2}{|c|}{15} \\
\hline
\end{tabular}


Table 2 Water quality parameters observed during the brood stock maintenance and larval rearing

\begin{tabular}{|c|c|c|c|c|c|}
\hline Parameter & Temperature $\left({ }^{\circ} \mathbf{C}\right)$ & Salinity $(\%)$ & $\mathrm{pH}$ & $\mathrm{DO}\left(\mathrm{mg} \mathrm{L}^{-1}\right)$ & Ammonia $\left(\mu \mathrm{M} \mathrm{L}^{-1}\right)$ \\
\hline Value & $27.21-31.97$ (29.3) & $28.56-37.13$ (33.2) & $7.98-8.49(8.26)$ & $4.59-6.05(5.46)$ & $0.171-1.539(0.95)$ \\
\hline
\end{tabular}

The values given in the parenthesis are average values.

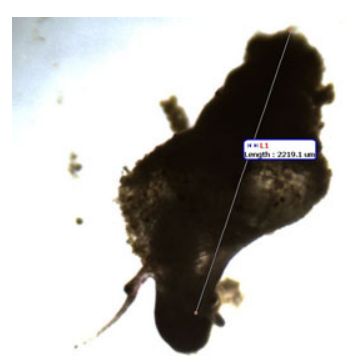

(a)

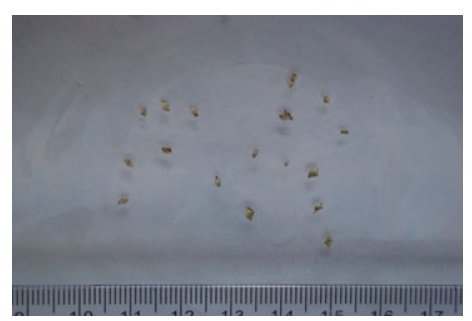

(c)

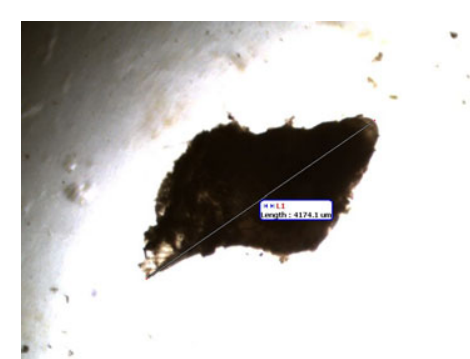

(b)

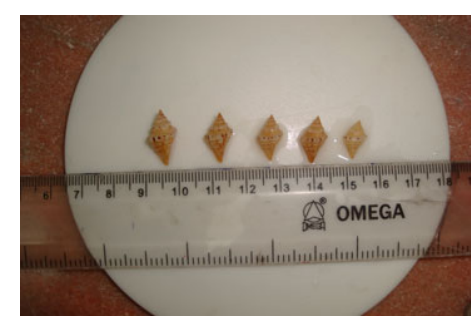

(d)
Figure 1 Post-metamorphic developmental stages of Lambis lambis into Juveniles. (a) 23rd day posthatch juvenile, (b) 43rd day old juvenile, (c) 55 days old juvenile and (d) 76 days old juvenile. [Colour figure can be viewed at wileyonlinelibrary.com].

Table 3 Details of larval feeding at different stages of larval development

\begin{tabular}{|c|c|c|c|c|}
\hline Days & Lambis lambis & Cypraea tigris & Chicoreus ramosus & \\
\hline Feed & $\begin{array}{l}\text { I. galbana } \\
\text { (cells } \mathrm{mL}^{-1} \mathrm{day}^{-1} \text { ) }\end{array}$ & $\begin{array}{l}\text { I. galbana } \\
\text { (cells } \mathrm{mL}^{-1} \mathrm{day}^{-1} \text { ) }\end{array}$ & $\begin{array}{l}\text { I. galbana } \\
\text { (cells } \mathrm{mL}^{-1} \text { day }^{-1} \text { ) }\end{array}$ & $\begin{array}{l}\text { Boiled clam meat } \\
\left(\text { g } 500 \text { numbers of larvae }{ }^{-1} \text { day }^{-1} \text { ) }\right.\end{array}$ \\
\hline $1-9$ & 8000 & 5000 & 8000 & - \\
\hline $10-19$ & 15000 & 10000 & 15000 & - \\
\hline $20-29$ & 50000 & - & - & 2 \\
\hline $30-40$ & 50000 & - & - & 4 \\
\hline
\end{tabular}

laid by two females. The egg case was creamy white in colour, vasiform shaped and contain gelatinous material for the protection of eggs. One aperture is present in the centre of the apical side covered with thin transparent membrane through which the larvae hatch out. The average length of the egg capsule laid during the spawning period ranged between 19.00 and $19.50 \mathrm{~mm}$ (Fig. 2a).

Eggs and fecundity. The fecundity varied among the brooders and it ranged from 600 to $1016 \mathrm{egg}$ cases. Each egg case contains 115-250 eggs with the diameter ranging from 350 to $400 \mu \mathrm{m}$ (Fig. 2b). The fertilized eggs present inside the egg case were ranged between $60 \%$ and $80 \%$ of total eggs. From the first brooder 245 egg cases have turned to pinkish colour and decayed after 15 days of spawning. In second instance 900 egg cases decayed out of 1016 egg cases laid. The incubation period varies from 22 to 35 days for C. ramosus. The embryo developed into a veliger and had two lobed velum and become active within the egg case. After the incubation period the veliger hatched through the aperture at the top of the egg case. It was observed that on an average 53 number of larvae were obtained from each viable egg case. The details are summarized in Table 4. 


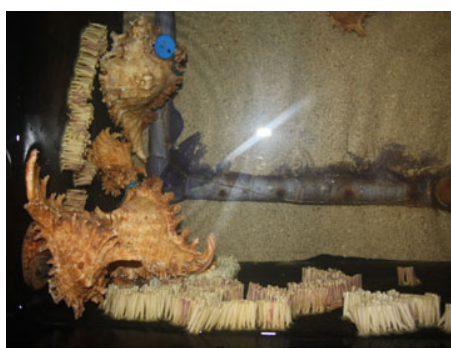

(a)

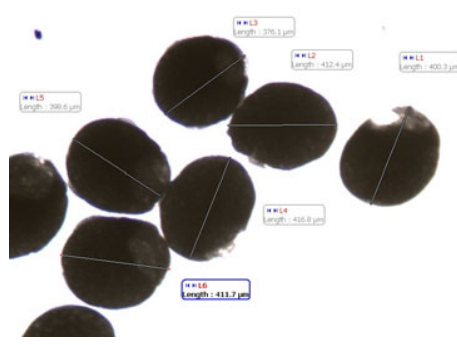

(c)

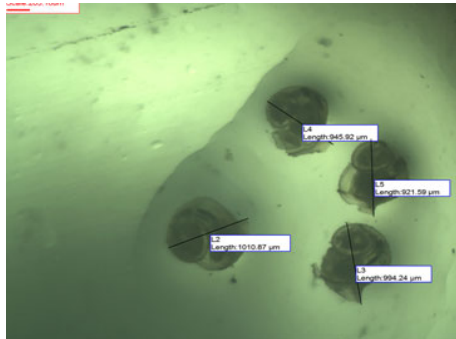

(e)

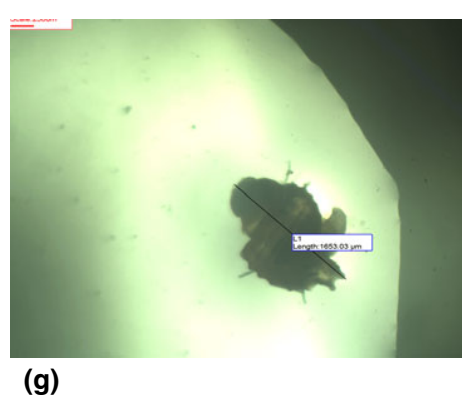

(g)

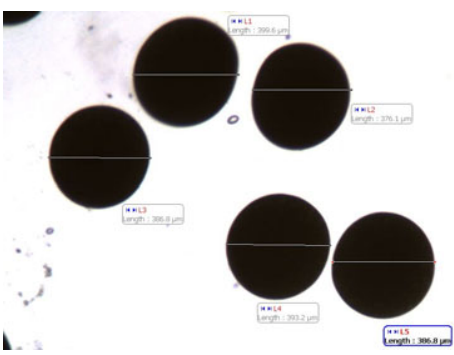

(b)

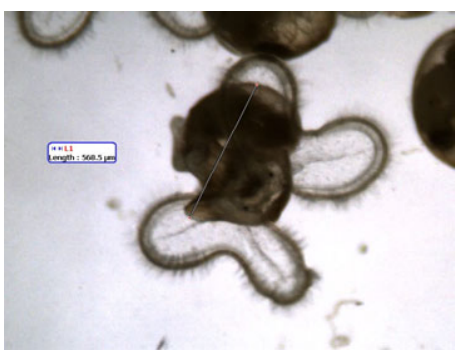

(d)

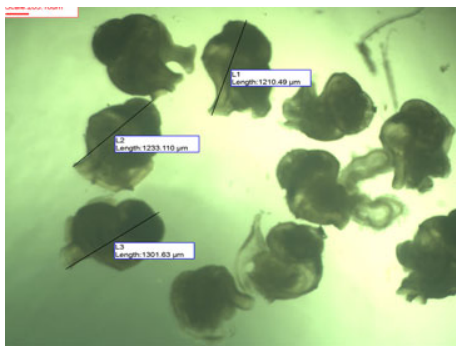

(f)

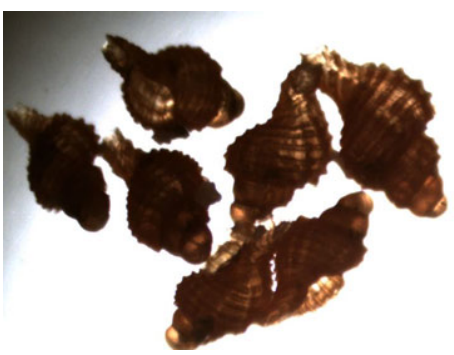

(h) wileyonlinelibrary.com].

Figure 2 Sequence of life cycle closing in Chicoreus ramosus. (a) Female laying egg cases, (b) fertilized eggs (1 dps), (c) fertilized eggs (9 dps), (d) veliger larvae (1 dph), (e) 10 dph larvae, (f) 20 dph larvae, (g) 30 days old juvenile, (h) juvenile of $C$. ramosus (45 days). Colour figure can be viewed at$$
\text { wileyonlinelibrary.com]. }
$$

Table 4 The spawning details of Chicoreus ramosus during the present study

\begin{tabular}{|c|c|c|c|c|}
\hline Batch & I & II & III & IV \\
\hline Duration of spawning & $12.01 .15-30.01 .15$ & 21.01.15-08.02.15 & $16.02 .15-02.03 .15$ & $03.03 .15-11.03 .15$ \\
\hline Spawning period (days) & 19 & 23 & 15 & 9 \\
\hline Total number of egg cases & 600 & 216 & 250 & 550 \\
\hline Decayed/pinkish egg cases & 245 & 100 & 180 & 410 \\
\hline \multirow[t]{3}{*}{ Total no. of larvae obtained } & 20800 & 7550 & 3440 & 5650 \\
\hline & Live: 13600 & Live: 6400 & Live: 2900 & Live: 4930 \\
\hline & Dead: 6200 (45\%) & Dead: 1150 (18\%) & Dead: 540 (19\%) & Dead: $720(15 \%)$ \\
\hline Avg. no. of larvae obtained/egg case & 59 & 65 & 49 & 40 \\
\hline
\end{tabular}


Larval development and growth. The veligers of C. ramosus, were free living and are active swimmers. The early larvae had a bi-lobed velum with very active cilia in the periphery of the velar lobe. The velum further divided into four lobes on 3 days post hatch. The shell size of newly hatched larvae ranged from 560 to $625 \mu \mathrm{m}$. The larval shell was transparent to pale brownish in colour with one whorl. The heart beat was visible clearly through the transparent shell. The eyes with short tentacle were observed clearly. Larval foot was in developing stage. Most of the larvae were freely swimming on the surface of the water column except few larvae which was found resting at the bottom of the tank.

The 10 day post-hatch larvae had a four lobed velum with active cilia. The shell colour turned into light brown and measured around 990$1050 \mu \mathrm{m}$ in size. The eyes were prominent with equally developed tentacle. The curve like structure formed in the middle portion of the outer lip of the shell. Foot was well-developed. Except few larvae all others were resting at the bottom of the rearing tank.

At 20th day post hatch, the four lobed velum were still remaining with the larvae. One thick growth line was noticed in the middle of the body whorl region. The shell turns into dark brown colour with two curvatures in the outer lip indicated the metamorphosis of larvae into juvenile. The siphonal canal increased in length and the shell size was around 1110-1280 $\mu \mathrm{m}$. All animals were metamorphosing and found at the bottom of the rearing vessel and started creeping on the algal mat developed in the bottom of the tank.

After 27 days post hatch, the larvae attained pre juvenile stage. Velum activity reduced and active foot movement was observed. The shell was darker in colour and second whorl partially developed. Four curves developed in the outer lip of the shell and size of the shell ranged from 1250 to $1400 \mu \mathrm{m}$.

The larvae have taken about 35-40 days to become juvenile. The completely metamorphosed juvenile had three whorls with lines. The shell was bright orange colour and the size was around 2400-2875 $\mu \mathrm{m}$. Velar lobes were disappeared and the juvenile was very actively crawling with their well-developed foot. Eyestalk became relatively long and equally developed tentacles. Seven spiny curves developed in the outer lip of the shell and horizontal parallel lines present in the body whorl. Slight curves developed in the sides of the siphonal canal. Thus, $8.8 \%$ of the prejuvenile transformed into juvenile. The developmental stages of C. ramosus and the growth rate of the larvae is given in Figs $2 \mathrm{~b}-\mathrm{h}$ and 3 .

Cyprids - C. tigris

Cypraea tigris brooders size/weight ranging from 83 to $96 \mathrm{~mm}$ (average size $89 \mathrm{~mm}$ )/165-230 g (average weight $197 \mathrm{~g}$ ) maintained under controlled condition spawned once during October 2014 (Fig. 4a). The colour of the egg case was pale grey and each egg case measured $2550 \mu \mathrm{m}$ in length and $1440 \mu \mathrm{m}$ in breadth (Fig. 4b). Neither the duration nor the number of egg cases could be counted as the brooding female was very stubborn in leaving the egg mass in spite of pressure applied on the brooders.

On 4 days post spawn (dps) the egg cases turn dark grey in colour and active veligers were seen within the egg case. The incubation period of the captive laid egg cases by the female brooder was 5 days. On 5 dps the egg cases hatched and veliger larvae emerged (Fig. 4c). The veliger of $C$. tigris measured 550-590 $\mu \mathrm{m}(537 \mu \mathrm{m})$. The larvae were active swimmers, had two prominent eyes, two lobed velum with cilia on its periphery and a transparent larval shell. From the spawning, a total of $3.84 \times 10^{5}$ veligers were obtained and the average number of veliger from single egg case was 686 . Based on the total estimated larvae retrieved and number of larvae in each single egg case, the probable number of egg case laid by a single $C$. tigris brooder is estimated to be approximately 560 .

The larvae were maintained in an algal diet of I. galbana at a concentration of 5000 cells larvae $^{-1}$ day $^{-1}$. On 5 days post hatch (dph), severe ciliate infection was observed and 50\% mortality of the larvae was occurred and thereafter was

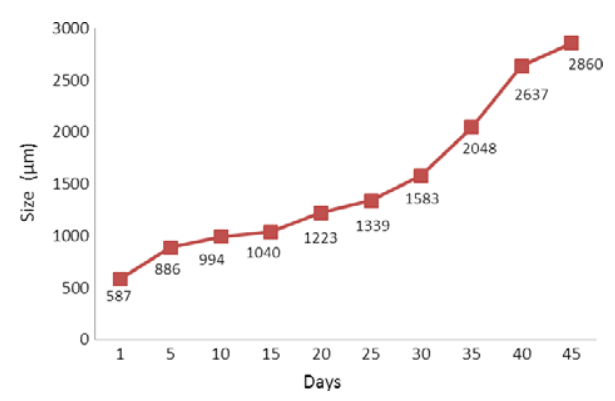

Figure 3 Shell growth of Chicoreus ramosus during larval development period. [Colour figure can be viewed at wileyonlinelibrary.com]. 
Figure 4 Spawning, egg case and veliger of Cypraea tigris. (a) Spawning in C. tigris, (b) egg case containing developing veliger and (c) veliger of $C$. tigris. [Colour figure can be viewed at wileyonlinelibrary. com].
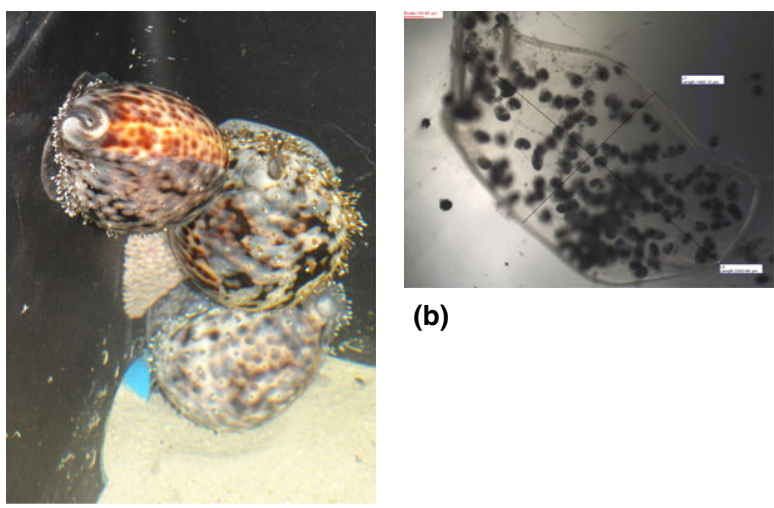

(b)

(a)

found to be continuous and drastic. The larval length grew to a size of 635-703 $\mu \mathrm{m}(668 \mu \mathrm{m})$ on $6 \mathrm{dph}$, on $9 \mathrm{dph}$ it grew to a size range of $762-776 \mu \mathrm{m}(769 \mu \mathrm{m})$ and on $14 \mathrm{dph}$ to an average size of $912 \mu \mathrm{m}$. Till this day, most of the larvae retained its cilia but activity was reduced. At this stage foot was more prominent and frequently protruding from the shell. The shell colour turned to brown. Further growth got restricted and survival of the larvae was observed for only 16 days post hatch and hence complete life cycle closing could not be achieved.

\section{Metamorphosis induction experiments}

Metamorphosis of larvae is natural in Muricids in 35-40 days post hatch whereas in Stombids (L. lambis) natural metamorphosis is observed in very small numbers Jagadis et al. (2012). To enhance the percentage of metamorphosing larvae, certain 'cue' is very critical at the competent level stage larvae. Hence, metamorphosis inductions in L. lambis larvae were attempted with chemical 'cue' using $\mathrm{H}_{2} \mathrm{O}_{2}$ in lower and higher concentrations, $\mathrm{KCl}$ in lower concentration levels and algal extract.

After each exposure time the larvae were examined under microscope for sign of metamorphosis such as lose of velum which revealed no visible changes occurred in the larvae treated with hydrogen peroxide at the rate of $10,50,100 \mu \mathrm{M}$

concentration and $\mathrm{KCl}$ at the concentration of 15 , 50 and $100 \mu \mathrm{M}$. Hydrogen peroxide at the concentration of 500 and $1000 \mu \mathrm{M}$ showed the arrest of ciliary activity after the exposure of $6 \mathrm{~h}$ and the velum got shrunken at $12 \mathrm{~h}$. But after $24 \mathrm{~h}$ of exposure, the larvae started dying and body tissues got eroded in most of the larvae. In case of seaweed Sargassum extract treatment no notable changes were observed within the stipulated exposure period but the larval mortality commenced after $48 \mathrm{~h}$ of exposure (Table 5).

\section{Disease control}

During the course of larval rearing of all the three groups of gastropods, the larvae was invariably affected by ciliates and were treated for ciliate infection by filtering them in the sieve and dipped for $10 \mathrm{~min}$ in $25 \mathrm{mg} \mathrm{L}^{-1}$ Chloramphenicol solution. The ciliate infection was effectively kept under control. Vorticella spp. infestations on the metamorphosed early juvenile were also observed to be a problem during the course of rearing.

\section{Discussion}

\section{Broodstock maintenance}

Broodstock of all the three groups was successfully maintained for years of holding under captive 
Table 5 Metamorphosis response of Lambis lambis larvae exposed to different chemical and natural cues

\begin{tabular}{llll}
\hline Treatment & Dosage & Exposure time & Observation \\
\hline $\mathrm{H}_{2} \mathrm{O}_{2}$ & $10,50,100 \mu \mathrm{M}$ & 6 & No visible change was occurred \\
& & 12 & \\
& & 24 & Cilia activity arrested \\
$\mathrm{H}_{2} \mathrm{O}_{2}$ & $500,1000 \mu \mathrm{M}$ & 68 & Velum got shrunken \\
& & 12 & Tissue eroded; animal died \\
$\mathrm{KCl}^{-}$ & 24 & No sign of metamorphosis was noticed & No noticeable changes of metamorphosis \\
Sargassum extract & $6,12,24 \& 48$ & were observed. But after 48 $\mathrm{h}$ of \\
& $100 \mathrm{mg} \mathrm{L} \mathrm{L}^{-1}$ & $6,12,24 \& 48$ & treatment the larvae started dying \\
\hline
\end{tabular}

condition. The environmental ambience maintained, water exchange and the feed protocol adopted in the experiments were found to be optimum for the three groups tested. Authors differ on the feeding habit of different species of cowries as carnivore, herbivore and spongivore. Meyer (2003) reported that Cyprids feed on algae, sponges and small organisms present in corals. Renaud (1976) noticed that Cypraea gaskonii feeds on sponges, Cypraea isabella on sponges and algae and Cypraea moneta on algae. Kay (1960) observed that Cypraea caputserpentis feeds on algae. Taylor (1975) found that Cypraea tered consumes on sponge. Darling (1965) witnessed that Cyprea spadicea can feed on frozen shrimp in the confinement. But, the present observations proved that C. tigris can be held under captivity for longer period (more than 2 years) on macro algal feed of Ulva sp. alone. The Strombids and Muricids are proved to be herbivorous and carnivorous, respectively, in the present study similar to the observations of Newell, Imbrie, Purdy and Thurber (1959) and Yonge (1930) who reported that Lambis sp. fed with Ulva sp. In case of Muricids, Tan and Oh (2002) found that Chicoreus capucinus feeds on mollusc and crustaceans and Jagadis et al. (2013) witnessed that $C$. virgineus feed on clam meat.

\section{Spawning, larval development}

\section{Lambis lambis}

Strombids were found to spawn during November to March. Similarly the observation made by different researchers corresponds to the period noticed in the present study. Shawl, Davis and Corsaut (2001) observed the spawning of strombid species during October to March. Hamel and Mercier
(2006) noticed during October and Manzano and Aranda (2004) observed hatching during March to May and September.

In case of L. lambis, the natural metamorphosis of larvae in to juvenile is very meagre as observed in the present study and indicated that the key was played by the need of a natural 'cue' that induces most of the competent larvae to metamorphose in to juvenile. Attempts made in this study with natural and chemical 'cues' at different concentrations were contra indicative and compels further experiments to determine the ambient dose and exposure time for large scale settlement of competent larvae of this species. The successful application of such 'cue' for large scale juvenile production had been worked out for temperate Strombids, S. gigas (Boettcher \& Targett 1996; Boettcher et al. 1997) and S. canarium (Cob et al. 2010).

\section{Chicoreus ramosus}

The spawning activity of C. ramosus takes place during December-March and in a communal pattern in the present study. The observations are more or less similar to that of the reports of following workers who have enlightened the spawning period of Muricids from different parts of the world. Bussarawit and Ruangchoy (1991) observed from June to December in Thailand. Mahmoud et al. (2013) found the spawning activity from the month of May to March in Egypt. Nugranad (1992) studied the larval stages of C. ramosus from September to April in Thailand.

Observations on the egg case morphology of C. ramosus in the present study was comparable to that of reports of Mahmoud et al. (2013). During the present study the number of egg cases and egg 
numbers varied from 216 to 600 egg cases per cluster and 115-260 eggs per egg case. Similar to the present result, Mahmoud et al. (2013) has observed that 405 egg cases per cluster and 117214 eggs per egg case, Nugranad (1992) noticed that 205-712 egg cases per cluster and 116-353 eggs per egg case and Ramesh, Edward and Ayyakannu (1992a) perceived that 67-698 egg cases per cluster and 25-267 eggs per egg case in the same species. Exceptionally, Ruangchoy and Tantichodok (1992) observed that egg cases in the range of 205-1214 per cluster and 132-735 eggs per egg case. In the present observation, from the total number of egg cases, $58 \%$ turned to purple colour indicating the decaying of egg cases after 15 days of post spawning. Similar observation was reported by Sreejaya (2008) in B. spirata where the egg capsules turn into pink and opaque when the capsules were infected by bacteria or fungus and Naegel (2004) in Plicopurpu pansa. The results of Gallardo (1973) as well as Riquelme and Chavez (1991) suggested the development of purple colour in nonviable capsules due to bacterial infection. In the current study the incubation period was 22-35 days in C. ramosus. This is in agreement with the reports of Bussarawit and Ruangchoy (1991) who found the duration of incubation period was 25-28 days.

In the present study, the larval rearing of C. ramosus was done with single species micro algal feed (I. galbana). However, Ramesh, Murugan and Ayyakannu (1992b) had fed the larvae of C. ramosus with mixed phytoplankton. The $1 \mathrm{dph}$ larval size was around $568 \mu \mathrm{m}$ which was similar to the observation of Ramesh et al. (1992b) who reported the size as 565-620 $\mu \mathrm{m}$. Transformation of metamorphosed larvae in to juveniles was observed on 35th day in the present study as compared with that of the $45 \mathrm{dph}$ by Ramesh et al. (1992b). Very less numbers of C. ramosus larvae only have transformed into juvenile stage which indicated the need for appropriate feed and suitable substratum for settling. This is in agreement with Ramesh et al. (1992b) who reported that delay in metamorphosis may be caused by lack of specific substratum and feed factor. According to Roller and Stickle (1989) in Thais haemostoma canaliculata the observed delay in metamorphosis may be due to insufficient nutrient. Similarly, Hahn (1988) reported the rate of larval development depends on water quality, stocking density and type of food.
Up to 20 days of post hatch the larvae were active and healthy. After 20th day the larvae started aggregating at the bottom of the tank and became weak followed by high larval mortality. This is attributed due to the bacterial infections during larval rearing. Such observations were reported by Disalvo, Blecka and Zebal (1978) in Ostrea edulis due to the toxin produced by Vibrio anguillarum that inhibit larval swimming where large numbers of larvae aggregate on the bottom of culture tanks.

In the present study, the life cycle closing was complete and the larval survival of C. ramosus achieved was $8.8 \%$. It confirms the findings of other authors on various larval rearing issues which determines better larval survival and transformation into juveniles, thus warranting for further concerted research in understanding the need for appropriate feed protocols and suitable substratum during post metamorphosis, prejuvenile and juvenile stages for mass juvenile production of Muricids beyond $3 \mathrm{~mm}$ size failing which the juveniles will perish.

\section{Cypraea tigris}

The observations made on the breeding of cyprid, C. tigris during the month of October under captive maintenance in the present study is first of its kind in Indian waters. Natarajan (1954) observed the wild spawning of Erronea errones in the month of September to April in Palk Bay. Katoh (1989) reported that Cypraea annulus having year round breeding season without any peak spawning activity at Cape Maeda in Okinawa. Murayama and Hirata (1968) reported the spawning of C. caputserpentis from March to July. The habit of brooding the egg mass is common among the cowry species and this habit was noticed in present study. This is in agreement with Yaninek (1978) who observed that $C$. tigris brooding the egg mass in the crevices on the surface of coral reef flats and C. lynx broods the egg mass during the night. Similarly, Jagadis (CMFRI 2010) has observed brooding of Cypraea caurica on egg mass laid in an empty pearl oyster shell and Cypraea arabica on the egg mass laid on a stone boulder in Tuticorin harbour basin during October. Kay (1960) reported that $C$. caputserpentis broods the egg mass for more than 2 weeks. In the present study, C. tigris broods the egg mass for 5 days and by that time the eggs were hatched. Similar to the observations of Murayama and Hirata (1968) who reported 
that the females brood the egg mass until it hatches.

The observations on cyprid $C$. tigris, it is found that though the hatched larvae from the egg masses are very viable, active and accepts the micro algal feed under controlled rearing condition, the larval development could not be completed as in the case of other two groups studied. The reason for the mortality in the cyprid larvae beyond 1-3 weeks of survival is yet to be confirmed and further research is required to understand the complete life cycle of this species.

\section{Metamorphosis induction}

Marine invertebrate larval metamorphosis can be influenced by several factors including physical, chemical and biological factors present in their environment (Burke 1983; Cameron 1986; Morse 1990; Pawlik 1992). However, in gastropods chemosensory cues present in juvenile environment acts as most predominant primary stimuli (Pechenik \& Heyman 1987; Lambert \& Todd 1994). In the present study, the metamorphosis of spider conch L. lambis was experimented with different chemical cues such as $\mathrm{H}_{2} \mathrm{O}_{2}$ and $\mathrm{KCl}$ as well as natural cue, crude aqueous extract of brown seaweed Sargassum sp. which were studied and reported in different species of gastropods by various workers. Unlike the reports of Boettcher and Targett (1996) who found successful metamorphosis by using water soluble and of low molecular size cues associated with red algae Laurencia poitei and epiphyte Fosliella sp., no visible change observed in the metamorphosis of L. lambis larvae until $48 \mathrm{~h}$ in the present study. Similarly, Morse, Froyd and Morse (1984) found that molecules from cyanobacteria and red algae induce the metamorphosis in Haliotis rufescens.

As indicated by several authors the excess concentration of potassium ions induce successful metamorphosis of many gastropod species such as H. rufescens (Baloun \& Morse 1984), Adalaria proxima (Todd, Bentley \& Havenhand 1991), Crepidula fornicate (Pechenik \& Heyman 1987) and Concholepas concholepas (Inestrosa, Campos \& Gonza'lez 1992). However, in the present study different level of potassium chloride was used to elevate the level of $\mathrm{K}^{+}$ions in the L. lambis larval rearing tanks to induce the metamorphosis but the larvae did not respond to $\mathrm{KCl}$. Among the three metamorphosis cues studied in the present experiment
$\mathrm{H}_{2} \mathrm{O}_{2}$ exhibited better performance than the rest of the two cues, $\mathrm{KCl}$ and Sargassum extract. In this experiment, $\mathrm{H}_{2} \mathrm{O}_{2}$ at higher dose $(500$ and $1000 \mu \mathrm{M})$ showed partial metamorphosis i.e. the larvae lost its ciliary activity within $6 \mathrm{~h}$ duration beyond that mortality was noticed. Similarly, Pires and Hadfield (1991) reported such partial metamorphosis in the nudibranch Phestilla sibogae by hydrogen peroxide treatment. However, Boettcher et al. (1997) got success in the commercial scale metamorphosis of $S$. gigas using hydrogen peroxide as metamorphosis inducing cue.

\section{Disease management}

Parasitic infection is very common in molluscan larval rearing. Several groups of protozoan parasites especially ciliates infect the larval stages of gastropods and cause severe mortality. Ciliate protozoan being an opportunistic scavengers they can cause mass mortality in molluscs following any stress. Very scanty information is available on the disease and control of gastropod larvae, hence, chloramphenicol, a potent antibiotic was used in the treatment of ciliate infection in the present study. Chloramphenicol at the dose of $25 \mathrm{mg} \mathrm{L}^{-1}$ effectively controls ciliate infection in the three species studied in this paper which gave a positive result in the control of ciliates.

\section{Acknowledgments}

The authors are expressing their sincere thanks to the Director, CMFRI, for the kind help and encouragement. They also thank the Head, Molluscan Fisheries Division, CMFRI, Kochi for his keen interest and encouragement in carrying out the studies. The authors thank the Scientist-in-Charge, TRC of CMFRI, Tuticorin for his kind help and facilities. The field assistance provided by Shri N. Jesuraj, Shri Sekar V. Rayer is acknowledged. The excellent support provided by Shri. J. Prince, in the hatchery is gratefully acknowledged.

\section{References}

Baloun A.J. \& Morse D.E. (1984) Ionic control of settlement and metamorphosis in larval Haliotis rufescens (Gastropoda). Biological Bulletin 167, 124-138.

Boettcher A.A. \& Targett N.M. (1996) Induction of metamorphosis in queen conch, Strombus gigas Linnaeus, larvae by cues associated with red algae from their 
nursery grounds. Journal of Experimental Marine Biology and Ecology 196, 29-52.

Boettcher A.A., Dyer C., Casey J. \& Targett N.M. (1997) Hydrogen peroxide induced metamorphosis of queen conch, Strombus gigas: tests at the commercial scale. Aquaculture 148, 247-258.

Brownell W.N. (1977) Reproduction, laboratory culture and growth of Strombus gigas, Strombus costatus and Strombus pugilis in Los Roques, Venezuela. Bulletin of Marine Science 27, 668-680.

Burke R.D. (1983) The induction of metamorphosis of marine invertebrate larvae: stimulus and response. Canadian Journal of Zoology 61, 1701-1719.

Bussarawit N. \& Ruangchoy T. (1991) The production and morphology of egg capsules and veliger larvae of Chicoreus ramosus. Phuket Marine Biological Centre Special Publication 9, 70-74.

Cameron R.A. (1986) Introduction to the invertebrate larval biology workshop: a brief background. Bulletin of Marine Science 39, 145161.

CMFRI (2010) Annual report 2009-2010, pp. 160. Central Marine Fisheries Research Institute, Cochin.

CMFRI-Cadalmin (2012) Hatcchery production of sea snail. Cadalmin-CMFRI Newsletter 135, 10.

Cob Z.C., Arshad A., Ghaffar M.A., Bujang J.S. \& Muda W.L.W. (2010) Development and growth of larvae of the Dog Conch, Strombus canarium (Mollusca: Gastropoda), in the laboratory. Zoological Studies 48, 111.

Darling S.D. (1965) Observations on the growth of Cyprea spadicea. The Veliger $\mathbf{8}, 14-15$.

Davis M. (2000) Queen conch (Strombus gigas) culture technique for research, stock enhancement and grow out markets. In: Recent advances in Marine Biotechnology Vol.4: Aquaculture, Part A: Seaweeds and Invertebrates (ed. by M. Fingerman \& R. Nagabhusanam), pp. 127-159. Science Publisher, Enfield, NH, USA.

Disalvo L.H., Blecka J. \& Zebal R. (1978) Vibrio anguillarum and larval mortality in a California coastal shellfish hatchery. Applied and Environmental Microbiology 31, 219-221.

Gallardo C. (1973) Desarollo intracapsular de Concholepas concholepas (Brugiere) (Gastropoda: Muricidae). Museo Nacional de Historia Natural (Chile) 16, 3-16.

Hahn K.O. (1988) Larval development of abalone. In: Handbook of Culture of Abalone and Other Marine Gastropods (ed. by K.O. Hahn), pp. 71-89. CRC Press, Boca Raton, Florida.

Hamel J.-F. \& Mercier A. (2006) Note on the spawning and development of the common spider conch Lambis lambis Jean. SPC Trochus Information Bulletin 12, 19-21.

Heslinga G.A. \& Hillmann A. (1981) Hatchery culture of the commercial top snail Trochus niloticus in Palau, Caroline Islands. Aquaculture 22, 35-43.

Inestrosa N.C., Campos E.O. \& Gonza'lez M. (1992) Induccio'n de metamorfosis en larvas de Concholepas concholepas por el ion $\mathrm{K}^{+}$. Boletin de la red Regional de agricultura de America Latina 6, 16-19.

Jagadis I., Shanmugasundaram K. \& Padmanathan J. (2012) Observations on broodstock maintenance, breeding and early larval development of the common spider conch Lambis lambis (Linnaeus, 1758) in captivity. Indian Journal of Fisheries 59, 165-169.

Jagadis I., Shunmugasundaram K., Sathakkathulla M. \& Mohanraj T. (2013) Spawning, intracapsular development and production potential of viable juveniles of a murex Chicoreus virgineus var. ponderosa Sowerby under laboratory conditions. Agricultural Sciences 4, 244-248.

Katoh M. (1989) Life history of the golden ring cowry Cypraea annulus (Mollusca: Gastropoda) on Okinawa Island, Japan. Marine Biology 101, 227-233.

Kay E.A. (1960) The functional morphology of Cypraea caputserpentis Linn. and an interpretation of the relationships among Cypraeacea. International Review of Hydrobiology 45, 175-196.

Lambert W.J. \& Todd C.D. (1994) Evidence for a waterborne cue inducing metamorphosis in the dorid nudibranch mollusc Adalaria proxima (Gastropoda: Nudibranchia). Marine Biology 120, 265-271.

Mahmoud M.A.M., Mohammed T.A.A. \& Yassien M.H. (2013) Spawning frequency, larval development and growth of Muricid gastropod Chicoreus ramosus (Linnaeus, 1758) in the Laboratory at Hurghada, Northern Red Sea, Egypt. Egyptian Journal of Aquatic Research 39, 125-131.

Manzano N.P. \& Aranda D.A. (2004) Development, growth and survival of the larvae of queen conch Strombus gigas under laboratory conditions. Aquaculture 242, 479-487.

Meyer C. (2003) Molecular systematics of cowries (Gastropoda: Cypraeidae) and diversification patterns in the tropics. Biological Journal of Linnean Society 79, 401459.

Middelfart P. (1992) Early life stages of the muricid gastropods Chicoreus ramosus, C. torrefactus and C. brunneus from Phuket Island, Thailand. Phuket Maine Biological Centre Special Publication 10, 113122.

Morse D.E. (1990) Recent progress in larval settlement and metamorphosis: closing the gap between molecular biology and ecology. Bulletin of Marine Science $\mathbf{4 6}$, 645-483.

Morse A.N.C., Froyd C. \& Morse D.E. (1984) Molecules from cyanobacteria and red algae that induce larval metamorphosis in the mollusc Haliotis rufescens. Maine Biology 81, 293-298.

Murayama S. \& Hirata K. (1968) Shell-bearing molluscs of the Uji Islets. Memoirs of Faculty of Fisheries Kagoshima University 17, 86-93.

Naegel L.C.A. (2004) Laboratory spawning of the purple snail Plicopurpu rapansa (Gastropoda: Buccinidae). Revista de Biologia Tropical 52, 10-17. 
Najmudeen T.M. \& Victor A.C.C. (2004) Seed production and juvenile rearing of the tropical abalone Haliotis varia Linnaeus 1758. Aquaculture 234, 277-292.

Natarajan A.V. (1954) On the breeding habits of the Cowry Erronea errones (Linne). Current Science 23, 225-226.

Newell N.D., Imbrie J., Purdy E.G. \& Thurber D.L. (1959) Organism communities and bottom facies, Great Bahama Bank. Bulletin of the American Museum of Natural History 117, 177-228.

Nugranad J. (1992) Experiemntal rearing of Chicoreus ramosus larvae at Prachuap Khiri Khan hatchery. Phuket Maine Biological Centre Special Publication 10, 5364.

Pawlik J.R. (1992) Induction of marine invertebrate larval settlement: evidence for chemical cues. In: Ecological Roles of Marine Natural Products (ed. by V.J. Paul), pp. 189-236. Comstock Publishing Associates, Ithaca.

Pechenik J.A. \& Heyman W.D. (1987) Using KC1 to determine size at competence for larvae of the marine gastropod Crepidula fornicata (L.). Journal of Experimental Marine Biology and Ecology 112, 27-38.

Pires A. \& Hadfield M.G. (1991) Oxidative breakdown products of catecholamines and hydrogen peroxide induce partial metamorphosis in the nudibranch Phestilla sibogae Bergh (Gastropoda: Opistho-branchia). Biological Bulletin 180, 310-317.

Ramesh M.X., Edward J.K.P. \& Ayyakannu K. (1992a) Reproductive biology of Chicoreus ramosus from Mandapam coastal waters, southeast coast of India. Phuket Maine Biological Centre Special Publication 10, 80-85.

Ramesh M.X., Murugan A. \& Ayyakannu K. (1992b) Larval development in Chicoreus ramosus. Phuket Maine Biological Centre Special Publication 10, 86-89.

Renaud M. (1976) Observations on the behaviour and shell types of Cypraea moneta (Mollusca: Gastropoda) at Enewetak, Marshall Islands. Pacific Science 30, 147158.

Riquelme C.E. \& Chavez P.C. (1991) Colonization of vibrios on developmental stages of Concholepas concholepas (Bruguière, 1789), (Mollusca: Muricidae). In: Ecology of Marine Aquaculture, A Workshop on Research in Aquaculture (ed. by K. Koop), pp. 84-95. International Foundation for Science, Stockholm, Osorno, Chile.

Roller R.A. \& Stickle W.B. (1989) Temperature and salinity effects on the intra capsular development, metabolic rates and survival to hatching of Thais haemastoma canuliculata (Gray) (Prosobrachia: Muricidae) under laboratory conditions. Journal of Experimental Marine Biology and Ecology 125, 235-251.

Ruangchoy T. \& Tantichodok P. (1992) Comparative morphology of egg capsules and Fecundity of Chicoreus ramosus from different localities. Phuket Maine Biological Centre Special Publication 10, 76-79.

Shanmugaraj T., Murugan A. \& Ayyakkannu K. (1994) Laboratory spawning and larval development of Babylonia spirata (L.) (Neogastropoda: Buccinidae). Phuket Maine Biological Centre Special Publication 13, 9597.

Shawl A. \& Davis M. (2004) Captive breeding behavior of four strombidae conch. Journal of Shellfish Research 23, 157-164.

Shawl A., Davis M. \& Corsaut J. (2001) Captive Breeding Behavior of Four Strombidae Conch. Aquaculture America, Florida.

Sreejaya R. (2008) Studies on spawning and larval rearing of the whelk, Babylonia spirata (Linnaeus, 1758) (Neogastropoda: Buccinidae). PhD thesis, Central Marine Fisheries Research Institute. Submitted to Cochin University of Science and Technology.

Sreejaya R., Mohan A., Laxmilatha P. \& Appukuttan K.K. (2004) Larval development and seed production of the whelk, Babylonia spirata (L. 1758) (Neogastropoda: Buccinidae). Journal of Marine Biological Association of India 46, 64-72.

Tan K.S. \& Oh T.M. (2002) Feeding habits of Chicoreus capucinus (Neogastropoda: Muricidae) in a Singapore mangrove. Bollettino Malacologico 38, 43-50.

Taylor J.D. (1975) The living cowrie. In: Cowries (ed. by J.D. Taylor \& J.G. Walls), pp. 7-49. T.F.H. Publications, Neptune, New Jersey.

Todd C.D., Bentley M.G. \& Havenhand J.N. (1991) Larval metamorphosis of the opisthobranch mollusc Adalaria proxima (Gastropoda: Nudibranchia): the effects of choline and elevated potassium ion concentration. Journal of the Marine Biological Association of United Kingdom 71, 53-72.

Yaninek J.S. (1978) A comparative survey of reef-associated gastropods at Maziwi island, Tanzania. Journal of the East Africa Natural History Society and National Museum 31, 165.

Yonge C.M. (1930) The crystalline style of the mollusca and a carnivorous habit cannot normally co-exist. Nature 125, 44-45. 